DOI: $10.12775 / \mathrm{MBS} .2014 .005$

Medical and Biological Sciences, 2014, 28/1, 29-34

ORIGINAL ARTICLE / PRACA ORYGINALNA

Aneta Mielnik

\title{
NUTRITION PATTERNS IN CHILDREN ATTENDING NURSERY SCHOOL IN SANOK VS. NUTRITIONAL GUIDELINES
}

\author{
PORÓWNANIE SPOSOBU ŻYWIENIA DZIECI UCZĘSZCZAJĄCYCH DO ŻŁOBKA NA TERENIE \\ MIASTA SANOKA Z AKTUALNYMI ZALECENIAMI ŻYWIENIOWYMI
}

Jan Grodek High Vocational School of Sanok, Instytut of Medicine, Nursing Department

Head: Anna Bednarek

Sum mary

Introduction: Nutrition is a particularly important environmental factor determining health. Research showed that the type of diet affects systemic changes and its influence is stronger at younger age. Breastfeeding is the optimum nutrition method for infants. This type of natural nutrition provides all dietary elements necessary for normal somatic growth and psychomotor development of a child and, at the same time, it comprises an important element of disease prevention. Parents' knowledge about current nutrition guidelines for infants as well as adjustment of this knowledge to individual needs of a particular child determine whether these recommendations are applied and measurable health outcomes are observed. The purpose of this study was to evaluate nutritional patterns, also introducing complementary foods like gluten and fish, during infancy vs. current infant nutrition guidelines.

Material and methods: The study group included 92 healthy infants and children between 10 and 55 months old attending two nursery schools in Sanok. Parents of these children were asked to fill a questionnaire form developed by the author. As a result information about breastfeeding and time of introducing gluten and fish to infant's diet was obtained. These results were compared with nutrition guidelines introduced in 2007. This type of comparison allowed the author to assess whether parents followed current nutrition guidelines for infants.

Results and conclusions: This study showed that introducing supplementary foods to infants' diet did not match current nutrition recommendations, both quantitatively and qualitatively. Therefore, it may be concluded that parents need to be educated in the field of nutrition adequate for children in order to ensure normal development of their children

\section{Streszczenie}

Wstęp: Żywienie jest szczególnie istotnym czynnikiem środowiskowym zdrowia człowieka. Badania dowodzą, iż rodzaj diety wywiera tym większy wpływ na kształtowanie ustrojowych przemian, im młodszy jest organizm. Optymalnym sposobem żywienia niemowląt jest wyłączne karmienie piersią. Karmienie naturalne zapewnia dostarczenie wszystkich składników koniecznych do prawidłowego rozwoju somatycznego oraz psychomotorycznego dziecka, stanowiąc jednocześnie ważny element profilaktyki chorób cywilizacyjnych. Wiedza rodziców na temat obowiązujących standardów żywieniowych niemowląt oraz dostosowanie jej do indywidualnych potrzeb każdego dziecka warunkuje stosowanie się do tych zaleceń i uzyskiwanie wymiernych efektów zdrowotnych. Celem pracy była ocena sposobu karmienia, wprowadzania pokarmów uzupełniających takich jak gluten i ryby w okresie niemowlęcym w świetle obowiązujących standardów żywieniowych. 
Materiał i metoda: Badania przeprowadzono wśród 92 dzieci zdrowych w wieku od 10 do 55 miesiąca życia uczęszczających do dwóch żłobków samorządowych na terenie miasta Sanoka. Do przeprowadzenia badań wykorzystano autorski kwestionariusz ankiety skierowany do rodziców dzieci. Na podstawie ankiet uzyskano informacje na temat karmienia naturalnego oraz oceniono czas wprowadzania glutenu i ryb do żywienia dzieci w okresie niemowlęcym. Uzyskane wyniki porównano do obowiązujących od $2007 \mathrm{roku}$ standardów w zakresie żywienia. Takie porównanie pozwoliło na ocenę realizacji przez rodziców aktualnie obowiązujących zasad żywienia dzieci.

Key words: infant nutrition, introducing supplementary foods.

Słowa kluczowe: żywienie niemowląt, wprowadzanie pokarmów uzupełniających.

\section{INTRODUCTION:}

Feeding is a main environmental factor which to a considerable degree decides on the somatic, mental and social health of man. Foetal and babyhood period is called the "critical period of an intense growth" on account of great dynamics of development of the organism and functional ripening of organs and of systems $[1,2]$. In this period dietary practices to a considerable degree can influence the formation of metabolic processes as well as programming of the ontogenesis $[1,2,3$, 4].

The first food which a newborn baby should receive is its mother's milk which will fully satisfy the demand for all basic nutritients, being an important component of the normal development and the prevention of many illnesses [1, 4, 5, 6 , $7,8,9,10,11,12,13,14]$.

In the babyhood period, apart from the way of feeding, adapting the kind and amounts of implemented supplementing foods are also essential.

Current recommendations concerning feeding children in the first year of life described in many academic publications result from progress of iatrology, mainly in the aspect of lowering the risk of the incidence of the coeliac disease result, obesity [9] and of deficiency of fatty omega 3 acids $[2,15]$. The scheme having been applied since 2007 of feeding babies recommends delivering products containing small amounts of gluten not earlier than in fifth and not later than in the sixth month of life $[5,6,9,14,16]$, and introducing fish from 6th month of life 1-2 times during the week [6].

Following principles of proper feeding, we provide the nutritients essential for every child which influence its normal development. The knowledge of parents as for the subject of dietary recommendations being in force and the compliance to these recommendations allows proper balancing the diet and adapting every child to its individual needs [4].

Since the $70 \%$ of the potential of the health of man depends on environmental factors which are possible to be modified, a promotion of health and a primary prevention led by health service employees should play the important role serving the improvement in the style of feeding children [4].

\section{MATERIALS AND METHODS:}

The research was conducted among 92 children in the age from 10 to 55 months of life attending the nursery in the town of Sanok. There were 47 boys (i.e. $51.1 \%$ ) and 45 girls (i.e. $48.9 \%$ ).

The studied children were in the following age
Wyniki i wnioski: Z przeprowadzonych badań wynikało, iż wprowadzanie pokarmów uzupełniających do diety niemowląt nie odpowiadało aktualnym zaleceniom żywieniowym, zarówno pod względem jakościowym jak i ilościowym. Na podstawie uzyskanych wyników można wnioskować, że konieczna jest edukacja rodziców w zakresie prawidłowego żywienia, aby zapewnić prawidłowy rozwój dzieci.

range: to 15 th month of life ( $n=5$ i.e. $5 \%$ ), from 16 th to 25 t. month of life $(n=19$ i.e. $21 \%)$, from 26 th to 35 th month of life $(\mathrm{n}=21$ i.e. $23 \%)$, from 36 th to 45 th month of life $(n=34$ i.e. $37 \%), 46$ months and above $(\mathrm{n}=13$ i.e. $14 \%)$. The medium age of the the studied population of children amounted to 33.84 month.

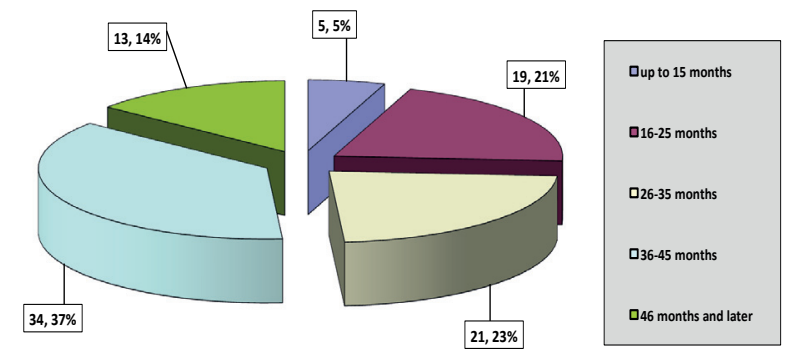

Fig. 1. The age of the studied babies.

The studied children largely came from full-term pregnancies (average duration of pregnancy - 39.5 week) from 40 to 42 of week - 61 (i.e. $66.3 \%$ ), from 37 to 39 of week - 25 (i.e. $27.2 \%$ ), from 32 to 36 of week - 6 (i.e. $6.5 \%$ ).

The body weight of the studied children in the moment of the birth developed as follows: below $2500 \mathrm{~g}$. $(\mathrm{n}=$ 4 i.e. $4 \%$ ), above $2500-3000$ g. $(n=14$ i.e. $15 \%)$, above 3000 - 3500 g. $(n=38$ i.e. $41 \%)$, above 3500 - 4000 g. $(n=30$ i.e. $33 \%$ ), above 4000 g. $(n=6$ i.e. $7 \%$ ). The average body weight of the studied children after the birth was $3365.59 \mathrm{~g}$.

An author's questionnaire of the questionnaire form directed at mothers of children attending the nursery was used for conducting research. The questionnaire contained general questions concerning the age and educating of the mother and the number of children in the family and detailed information concerning the knowledge and of applying the current pattern of feeding babies (including natural feeding, implementing the first supplementing meals and suplementation of diets with vitamins). Mothers were also asked about how they obtained information on dietary practices for children.

Statistical analysis was conducted in two stages: descriptive statistics and analytical statistics. For quantitative variables typical descriptive statistics were calculated i.e.: the average value (M), standard deviation (SD), minimum values (Min.) and maximum values (Max.). For the evaluation of the relations between quality variables Chi- square tests were used: Pearson's Chi - square and Fisher's accurate test. The analytical part was based on the method of generalized linear and non-linear analysis using Statistica program. P value < 0.05 was halimed as statistically significant. 


\section{RESULTS:}

Mothers with high/undergraduate education were the largest group of 66 individuals (i.e. $71.7 \%$ ) and with secondary -22 individuals (i.e. $23.9 \%$ ), mothers with vocational education were a minority -4 individuals (i.e. $4.3 \%)$. The majority of mothers had only one child $(n=42)$ [two children $(\mathrm{n}=37)$, three children $(\mathrm{n}=12)$ four or more $(\mathrm{n}$ $=1$ ) (on average 1.69)]. Most mothers were in an age bracket of 31-35 years $(n=39$ i.e. $42.4 \%)$ and $26-30$ years $(n=32$ i.e. $34.8 \%)$, remaining $10(10.9 \%)$ in the age from $21-25$ years of life, 9 women i.e. the $9.8 \%$ in age 36 - 40 years of life, one woman below 20 and one above 40 .

Majority of the studied ( $\mathrm{n}=78$ i.e. $84.8 \%$ ) declared that they knew and applied scheme in force of feeding babies, $67.4 \%$ of the studied obeyed both quantitative and quality rules, $15,2 \%$ - quality, one only quantitative ones. $16.3 \%$ of individuals did not answer question concerning dietary practices. Mothers in the overwhelming majority (it concerned $96 \%$ of the studied) declared that they had breast-fed their children, but the time of the natural feeding was different. Mothers breast-fed their children from birth for the total period: of 1 month $(n=9$ i.e. $10 \%)$, of 2 months ( $n=8$ i.e. $9 \%)$, of 3 months ( $\mathrm{n}=14$ i.e. $16 \%)$, of 4 months $(\mathrm{n}=8$ i.e. $9 \%), 5$ months $(n=11$ i.e. $13 \%), 6$ months $(n=21$ i.e. $25 \%), 7$ months $(\mathrm{n}=2$ i.e. $2 \%), 8$ months $(\mathrm{n}=5$ i.e. $6 \%), 9$ months $(\mathrm{n}=2$ i.e. $2 \%), 12$ months ( $\mathrm{n}=1$ i.e. $1 \%), 14$ months $(\mathrm{n}=2$ i.e. $2 \%), 15$ months $(n=1$ i.e. $1 \%), 18$ months $(n=3$ i.e. $3 \%)$, of 24 months $(\mathrm{n}=1$ i.e. $1 \%)$.

Respondents asked about the time of administration of milk blends answered: from birth $(\mathrm{n}=9$ i.e. $9.8 \%)$, from 2nd month of life ( $\mathrm{n}=11$ i.e. $12.0 \%$ ), from 3 - 4 of month of the life ( $\mathrm{n}=26$ i.e. $28.3 \%)$, from 5 - 6 of month of life $(n=30$ i.e. $32.6 \%$ ), from $7-8$ of month of life ( $n=7$ i.e. $7.6 \%$ ), from 9 - 10 of month of life $(n=8$ i.e. $8.7 \%)$. One mother did not answer.

Mothers gave as the most frequent causes of beginning applying milk blends: insufficient amount of breast milk (52.9\% of observations), return to the career $(29.9 \%$ of observations) and commissioning of the doctor $(19.5 \%$ of observation). Remaining mothers reported: other problems resulting from the breast-feeding, appearing allergy in a child, illness of the mother, or the dislike for the suction of the breast by the child.

Overwhelming majority of the questioned women (i.e. $42.4 \%$ ) introduced foods containing gluten at about 1 st year of age of the child into the diet of the child (in $10-12$ month), next $19.6 \%$ in $7-9$ month, $16.3 \%$ in $5-6$ month of the life, $19.6 \%$ did not administer gluten in the first year of life

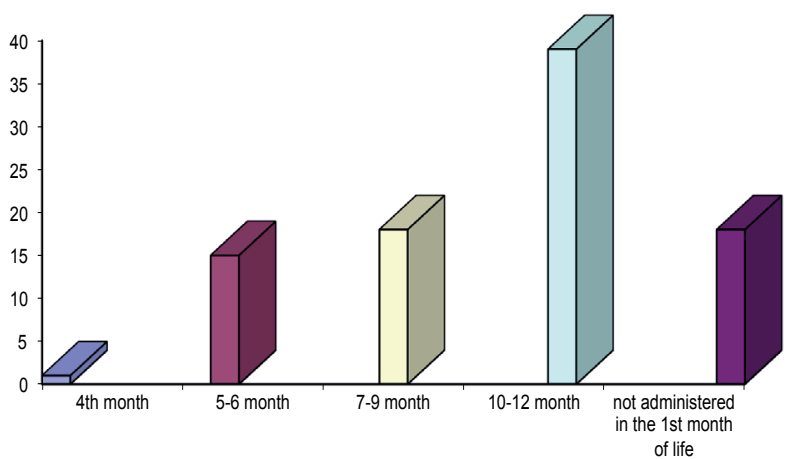

Fig. 2. The month of implementing glutenous foods for babies.
Correlation of the time of implementing gluten foods ( $p=$ 0.692) with age of the children wasn't essential statistically

\begin{tabular}{|l|c|c|c|c|}
\hline $\begin{array}{c}\text { The month of introducing } \\
\text { of gluten food }\end{array}$ & Count (N) & $\begin{array}{c}\text { Average } \\
\text { (M) }\end{array}$ & $\begin{array}{c}\text { Standard deviation } \\
\text { (SD) }\end{array}$ & $\mathbf{p}$ \\
\hline 4th month & 1 & 18.0000 & & \\
5-6th month & 15 & 32.0667 & 10.04608 & \\
7-9th month & 18 & 33.9444 & 12.44504 & $\mathbf{p}=\mathbf{0 . 6 9 2}$ \\
10-12th month & 39 & 35.1538 & 10.76920 & \\
Not administered & 17 & 33.2353 & 11.22792 & \\
\hline
\end{tabular}

Table I. Month of implementing gluten foods and the age of the studied children.

In the first year of life introducing of fish foods into foods of the child was declared by 48 mothers - $58 \%$ of the studied, 44 i.e. $48 \%$ did not give fish at all. Omega 3 acids (in the form of preparations) were given by $43 \%$ of the studied $(\mathrm{n}=40)$, remaining $57 \%$ respondents $(\mathrm{n}=52)$ did not declare diet supplementation with omega 3 acids. Up to 1 year of age supplementation with omega 3 acids covered - 10 children, to 18 of month - 8 children, to 24 of month - 11 children, to 36 of month -6 children, a reply was not given from 5 mothers (Tab. II., Fig. 3).

\begin{tabular}{|c|c|c|c|c|}
\hline $\begin{array}{c}\text { Administration of } \\
\text { Omega } 3 \text { acids }\end{array}$ & $\begin{array}{c}\text { Count } \\
\text { (N) }\end{array}$ & Average (M) & $\begin{array}{c}\text { Standard deviation } \\
\text { (SD) }\end{array}$ & $\mathbf{p}$ \\
\hline YES & 40 & 36.1000 & 9.22316 & $\mathbf{p}=\mathbf{0 . 0 8 3}$ \\
NO & 52 & 32.1154 & 11.85973 & \\
\hline
\end{tabular}

Table II. Supplementation with omega 3 acids of baby diets.

Correlation concerning supplementation with omega 3 acids was not essential statistically ( $p=0.083$ ) (Table II.).

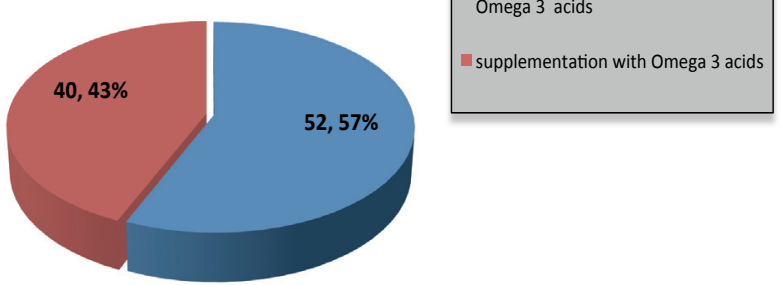

Fig. 3. Supplementation of the diet of babies with preparations containing omega 3 acids.

Most often listed sources of information for mothers about current dietary practices of babies are mainly books, booklets and magazines (83.5\% of observations), and: family (50.5\% of observation), Internet (48.4\% of observations), paediatrician $(46.2 \%$ of observations), acquaintances $(25.3 \%$ of observations), midwife (24.2\% of observations), POZ doctor $(11.0 \%$ of observations), own experience $(2.2 \%$ of observations), TV programmes (2.2\% of observations).

\section{DISCUSSION:}

First periods of the child development are very essential for the somatic and psychomotor normal development as well as for establishing correct eating habits. Dietary mistakes made in this period to a considerable degree influence cognitive abilities and the development [1].Wrong 
eating habits appear already at the infancy and babyhood and result from the wrong way of breastfeeding techniques, of early over-feeding or administering drinks of liquids sweetened with sugar [1]. Too early introduction of cereals, meat, sweetened fruit juices into the diet of the baby and vegetable is wrong. Children are fed with cow's milk too early. They consume milk products (yogurts and cheese) before the seventh month of life are given citrus fruit before they are 6 months old.

A large percent of mothers preparing vegetable meals or vegetable - meat meals independently do not add the appropriate amount of unsaturated fats to them. It often becomes a practised habit to over-drink kids with herbal teas at different times of the day and early exposure of the child to sweets and salt [3]. A lifestyle of the family to a large extent is determined by the level of education of parents which affects the choice of the specific model of feeding $[10,17]$. In the analysed population, the beneficial situation resulted from the fact that mothers constituting the largest group were those with high/undergraduate and secondary education. Based on a statistical analysis a relation wasn't demonstrated that educating the mother had affected: acquaintance of the up-todate scheme of feeding babies and applying it, of obtaining information about feeding from various sources: from POZ doctor, paediatrician, midwife, acquaintances, family, books, magazines, Internet, whether from own experience.

Information about feeding children was taken mainly from books and magazines, from the family, or from the Internet - definitely they more rarely acquired the professional knowledge from the medical staff. A half of the surveyed mothers could not use the knowledge of own experience because it was their first child. Few women give television as sources of information which can be connected with a paucity of media programs about the dietary subject matters.

The studied mothers knew about quantitative and quality rules of feeding and can generalny apply the scheme of feeding $(80.5 \%)$. Majority of the studied $(n=78$ i.e. $84.8 \%)$ declared that they knew and applied in practice scheme in force of feeding babies. A fact that over $15 \%$ mothers had no such knowledge is alarming. $67.4 \%$ of the studied obeyed both quantitative and quality rules. However, $15.2 \%$ applied only the rule pertaining to quality; one person - only the quantitative rules. $16.3 \%$ of individuals did not answer a question what can also provide the knowledge to this subject. In spite of the subjective very good self-assessment of mothers about the acquaintance of the up-to-date scheme of feeding babies, applied feeding in practice did not correspond to both quality and quantitative recommendations being in force.

Between the model of breastfeeding children in the natural and in the artificial way crucial differences exist. The food which a newborn and a baby should receive during the first six months of the life is definitely mother's milk. According to a current model of feeding (2007), the breastfed babies by the 1st half-year should not receive other supplementing meals, only additional meals (in 5 - 6 month) in the form of the porridge or cereal gluten pap. In the 2 nd halfyear a continuation is being recommended at the request of the breast-feeding and gradual introduction of supplementing meals $[1,4,5,6,7,9,10,11,12,13,14,18]$.

In the scheme of feeding newborn babies, artificially served initial milk is recommended in the first six months of the life of the child, and in the following 6 months

- the next step milk. Gradual introduction of the food supplemented in fruits, vegetables should start from 5 th month of life $[5,6,9,14,18]$. Too early introduction of the first supplementing meals can unduly burden the immature body of the baby which is poor tolerating complex carbohydrates still (e.g. starch), to influence functions of the excretory system, or to constitute the increased risk of nutritional allergy [17].

Current changes in feeding babies in the first year of life concern the prevention of the appearance of the coeliac disease and the supply of mainly fatty omega - 3 acids.

The frequency of appearing of the coeliac disease is from 1: 100 to 3: 300 individuals. The coeliac disease is second after the lactose intolerance metabolic disease, at least recently many other factors can affect its incidence. According to Köttgen theory, environmental, infectious and immunologic genetic factors also play the decisive part in its genesis [19]. Taking into consideration the fact that a clinical picture of illness has been changed from the classical form nonsymptomatic, or untypical - the greater role is being assigned to the popularization of the natural breastfeeding and early introduction of gluten to the diet of the baby. The great significance for the protection against the coeliac disease is played by the amount and the time of implementing gluten. As it is established by research (before 3rd month of life) as well as too late (after 7th month of life) introduction of gluten into the diet of the child the risk of falling ill with the coeliac disease in later years increases $[19,20]$.

The scheme of feeding babies introduced in 2007 recommends introducing products containing small amounts of gluten already in the fifth month of life of the child and not later than in the sixth month $[5,6,9,14,16]$. Implementing gluten according to new guidelines results in only $1 \%$ of children that may suffer from coeliac disease, so its elimination in food products at all children seems pointless. Gradual introduction of gluten into the diet causes learning the nutritional tolerance and lowers the risk of the coeliac disease $[1,5,6,9,13,14$, $18,20]$. Implemented gluten in the period when breast-feeding dominates also lowers the risk of falling ill with other illnesses i.e. type 1 diabetes and allergy to the wheat [21].

In the the studied population, only $16.3 \%$ of mothers implemented foods containing gluten according to applicable rules of feeding; mistakes in this issue hmore often concerned a too late supply of gluten - most often about 1 year of age. Nearly $1 / 5$ of the studied (i.e. 19.6\%) did not give gluten in foodstuffs before finishing first year of life. The fats in all periods of the development of a man constitute the essential element of food, performing a lot of folded physiological functions. In the babyhood period it comes to the fast increase in weight and the development of organs, mainly the central nervous system. The pace of development of the brain depends among others on amount and fat delivered to the quality [2]

In the diet of the child not only a quantity of accepted fatty products, but also their type is important. Fats appear in the form of saturated and unsaturated acids. Longchain polyunsaturated fatty acids are, among others, important components of cell membranes and structures of the human brain which participate in different compound his functions [2, $15]$.

At present much attention is devoted to complementing babies and small children's diet with preparations containing long-chain fatty acids, of which fish is a primary source. Poland, on account of its geographical situation and small consumption of saltwater fishes and piscine oil, belongs to the countries particularly theatened with the deficiency of long-chain saturated fatty acids [1, 22, 23, 24]. Apt guidelines concerning feeding signify the appropriate supply of fatty omega - 3 acids to babies in the form of fish 
introduced into the diet from the 7th month of life and for babies breastfed in the artificial way, already from the 6 th month $[5,6$, 14]. The appropriate level of that kind of fatty acids results in the improvement in the psychomotor development of children and the pace of matuartion of the visual acuity.

Omega-3 fatty acids are important for somatic and psychomotor development of children starting from the baby age, through babyhood, and ending with the school period [15]. Omega- 3 acids in the diet of a small child improve the ability to remember, are hastening thought processes, streamlining the concentration as well as increasing the intelligence quotient (IQ). They also play an important role in the regulation of the dream, reduce the stress, aggression and the children's hyperactivity, improve the eyesight as well as demonstrate the effectiveness in curing dyslexia, and can also lead to reducing manifestations of ADHD at children [15p. 52].

Consuming omega - 3 acids in the form of fish is an element of prevention, among others, of cardiovascular diseases (they improve the lipid economy, the blood pressure, the susceptibility of arteries, functions of the endothelium and acts anti-thrombotic and anti-inflammatory) Therefore, the Polish Society of the Research on Atherosclerosis and the Polish Paediatric Society introduce a program of preventing deficiencies of this acids in the everyday diet of pregnant women, babies and children [15].

A demand for fish products being a source of saturated fatty acids already exists in the period of pregnancy. On account of the risk of consuming inappropriate fish one should eat fish appropriate for their kind. Smoked or frozen fish and seafood should be avoided because of the risk of infection with listeriosis, parasites, noroviruses, while eating raw crustaceans and the seafood can be a source of toxoplasmosis infection. In the process of preparing fish it matters greatly to apply adequate hygiene concerning washing hands [26].

Almost a half of mothers in the first year of a child's life do not give fish products to their children, or no dietary supplements. Giving Omega 3 acids in the studied population concerned the $43 \%$ of children; remaining $57 \%$ did not declare suplementation.

In reference to recommendations of experts from the field of paediatrics and the research on atherosclerosis, a rich diet of EPA fatty acids (eikosapentaen) and DHA (dekozaheksaenowy) from 1.0 to $1.5 \mathrm{~g}$ it recommended in everyday meals of women and babies from 6th week of the life [15]. Considering the quality of fish products and the possibility of presences of pollutants absorbed by fish (mainly mercuries and/or of dioxins), limited delivery of some saltwater fishes mainly salmon and tuna fish is often more beneficial than once a week by expectant mothers and small children between 2 th and 7 th year of age. On that account this group should be embraced by suplementation of controlled permanent EPA content and DHA $[2,15]$.

\section{CONCLUSIONS:}

1. Introduction of supplementing foods into babies's diets does not correspond to apt dietary recommendations.

2. Demonstrating the irregularity in feeding of the studied group of children testifies to the necessity the education of mothers, bearing in mind a proper development of a child.

3. Subjective, very good self-assessment of mothers on the acquaintance of the up-to-date scheme of feeding babies and applying it in practice does not correspond to recommendations being in force (2007) both as for quality and quantitative aspects.

\section{REFERENCES:}

1. Socha J., Socha P., Weker H.: Żywienie dzieci a zdrowie wczoraj, dziś i jutro. Pediatria Współczesna. Gastroenterologia, Hepatologia i Żywienie Dziecka 2010, 12, $1: 34-37$

2. Pac-Kożuchowska E.: Rola kwasów tłuszczowych omega 3 w żywieniu dzieci. Czynniki ryzyka 2/2009: 35-40.

3. Ignyś I.: Najczęstsze błędy żywieniowe [w:] Żywienie dzieci w zdrowiu i chorobie. Krawczyński M. (red). Wydawnictwo Helpmed, Kraków 2008: 61-62.

4. Socha J.: Żywienie a rozwój dziecka w pierwszym roku życia. Nowa Pediatria 2002, 2(29): 96-102.

5. Agostini C., Decsi T., Fewtrell M.: Wprowadzanie pokarmów uzupełniających. Komentarz Komitetu ESPGHAN ds. Żywienia. Medycyna Praktyczna Pediatria, maj - czerwiec 2008, 3 (57): 45-61.

6. Dobrzańska A., Czerwionka-Szafarska M., Kunachowicz H.: Zalecenia dotyczące żywienia dzieci zdrowych w pierwszym roku życia opracowane przez zespół ekspertów powołany przez konsultanta krajowego w dziedzinie pediatrii. Pediatria po Dyplomie Wydanie specjalne 2008, wrzesień: 8-15.

7. Kowalewska-Kantecka B.: Karmienie pokarmem matki złotym standardem żywienia noworodków i niemowląt. Pediatria Współczesna. Gastroenterologia, Hepatologia i Żywienie Dziecka 20079 (1): 65-68.

8. Krauss H., Ignyś I., Sosnowski P.: Karmienie naturalne, a rozwój dziecka. Pediatria Współczesna. Gastroenterologia, Hepatologia i Żywienie Dziecka 2009, 11, 4: 145-152.

9. Książyk J. B., Weker H.: Nowe zalecenia żywienia niemowląt w Polsce od roku 2007. Pediatria Współczesna. Gastroenterologia, Hepatologia i Żywienie Dziecka 2007, 9 , 4: 292-297.

10. Ligenza I., Jakubowska-Pietkiewicz E., Łupińska A.: Ocena sposobu żywienia noworodków i niemowląt hospitalizowanych w Klinice Propedeutyki Pediatrii i Chorób Metabolicznych Kości oraz analiza czynników wpływających na wybór sposobu karmienia dzieci. Polski Merkuriusz Lekarski 2009, XXVI, 156: 605-608.

11. Łoś-Rycharska E., Adamska I., Swincow G.: Średnia masa ciała dzieci w wieku do 18 miesiąca życia karmionych naturalnie i mlekiem modyfikowanym. Wiadomości lekarskie 2006, LIX: 5-6.

12. Łoś-Rycharska E., Kiejdo P., Czerwionka-Szafarska M.: Wpływ sposobu żywienia dzieci w wieku niemowlęcym na masę ich ciała w wieku przedszkolnym. Polski Merkuriusz Lekarski, 2007, XXII, 130, 263-268.

13. Szajewska H., Albrecht P., Dziechciarz P.: Postępy w gastroenterologii i żywieniu dzieci w 2007 roku. Medycyna Praktyczna Pediatria 2 (56), marzec-kwiecień 2008: 51-64.

14. Dobrzańska A., Czerwionka-Szafarska M., Kunachowicz H.: Zalecenia dotyczące żywienia dzieci zdrowych w pierwszym roku życia, opracowane przez zespół ekspertów powołany przez konsultanta krajowego ds. pediatrii. Pediatria po Dyplomie. Vol.11 nr 4, sierpień 2007: 93-96.

15. Pac - Kożuchowska E.: Kwasy thuszczowe omega - 3 a stan zdrowia dzieci. Endokrynologia Pediatryczna, Vol. 7/2008, nr 4(25): 49-54.

16. Sawiec P., Książyk J.: Kontrowersje w pediatrii - Czy gluten należy wprowadzać do diety dziecka po ukończeniu 4 miesiąca życia, a przed ukończeniem 6 miesiąca życia?. Medycyna Praktyczna Pediatria, listopad - grudzień 2007: $15-33$. 
17. Gawęda A., Woś H.: Żywienie uzupełniające niemowląt $\mathrm{i}$ dzieci w wieku poniemowlęcym z terenu Górnego Śląska. Borgis, Nowa Pediatria 1/2008: 13-17.

18. Adamska I., Czerwionka - Szafarska M.: Profilaktyka alergii pokarmowej u dzieci. Standardy medyczne Pediatria, 2010, T. 7: 580-589.

19. Grzymisławski M., Stankowiak-Kulpa H., Włochal M.: Celiakia - Standardy diagnostyczne i terapeutyczne 2010 roku. Forum Zaburzeń Metabolicznych 2010, tom.1, nr 1: 12-21.

20. Mowszet K., Piasecka A., Reich M.: Ujawnienie się choroby trzewnej u dzieci $\mathrm{w}$ zależności od sposobu żywienia. Pediatria współczesna. Gastroenterologia. Hepatologia i Żywienie Dziecka. 2007, 9, 1: 17-21.

21. Horvath A., Dziechciarz P.: Żywienie dziecka w 1. roku życia. Standardy medyczne/Pediatria. 2010, T. 7: 563 566.

22. Saldeen P., Saldeen T.: Rola kwasów thuszczowych omega-3 u kobiet. Medycyna Praktyczna (Ginekologia i Położnictwo), 3 (37) maj - czerwiec 2005: 83-94.

23. Jańczyk W., Socha P.: Wpływ suplementacji kwasu dokozaheksaenowego (DHA) na częstość infekcji dróg oddechowych u dzieci poniżej 3. roku życia. Zapotrzebowanie na kwas dokozaheksaenowy u małych dzieci. Standardy medyczne/Pediatria 2010, T. 7: 555-557.

24. Weker H., Więch M.: Suplementacja w żywieniu kobiet w okresie ciąży i laktacji - aktualne spojrzenie. Standardy medyczne / Pediatria 2010, T. 7: 569-578.

25. Stolarczyk A., Socha P.: Tłuszcze w żywieniu niemowląt. Nowa Pediatria 3 (30) 2002: 200-202.

26. Czerwonogrodzka - Senczyna A., Ehmke vel Emczyńska E.: Prawidłowa dieta w ciąży - zasady ogólne. Położna nauka i praktyka, 2 (10) /2010: $52-56$.

\section{Address for correspondence:}

Aneta Mielnik

Jan Grodek High School of Sanok, Instytut of Medicine,

Nursing Department

Mickiewicza 21, 38 - 500 Sanok

e-mail: a.mielnik@op.pl

tel. 723521220

fax. 134655961

Received: 19.06.2013

Acceoted for publication: 07.01.2014 